\title{
Implementation and Evaluation of Teachers' Performance Supervision at Madrasah Aliyah (Islamic Senior High School)
}

\section{Muhammad Tambrin ${ }^{1}$, Iim Wasliman ${ }^{2}$, Hanafiah $^{3}$, Achmad Mudrikah ${ }^{4}$}

1,2,3,4 Postgraduate Faculty, Universitas Islam Nusantara Bandung, Indonesia

\section{A R T I C L E I N F O}

Article history:

Received March 07, 2021

Revised March 10, 2021

Accepted October 24, 2021

Available online November 25, 2021

\section{Kata Kunci :}

Efektivitas, Pengawasan, Kinerja Guru

\section{Keywords:}

Effectiveness, Supervision,

Teacher Performance

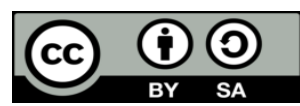

This is an open access article under the CC BY-SA license.

Copyright (C) 2021 by Author. Published by Universitas Pendidikan Ganesha

\begin{abstract}
A B S T R A K
Mencermati kualitas pendidikan hendaknya mengikutsertakan guru sebagai garda terdepan dalam dunia pendidikan. Kurikulum dan program yang baik pun tidak akan ada artinya jika guru tidak melaksanakannya secara bertanggung jawab dan konsisten. Penelitian ini bertujuan untuk menganalisis program supervisi kinerja guru, menyelenggarakan program supervisi kinerja guru, gerakan dan kepemimpinan supervisi kinerja guru, pengendalian efektivitas supervisi kinerja guru, dan ide-ide kreatif dan inovatif dalam mewujudkan efektivitas supervisi kinerja guru. Penelitian ini menggunakan pendekatan kualitatif dengan metode Studi Kasus. Metode yang digunakan untuk mengumpulkan data yaitu wawancara, observasi dan dokumentasi. Instrumen yang digunakan untuk mengumpulkan data yaitu kuesioner. Subjek penelitian atau responden penelitian dipilih secara purposive. Teknik yang digunakan untuk menganalisis data yaitu analisis deskriptif kualitatif. Hasil penelitian ini adalah pertama, program perencanaan belum terlaksana secara efektif karena masalah keterbatasan sumber daya. Kedua, penyelenggaraan pengawasan belum dilakukan secara optimal. Ketiga, gerakan dan kepemimpinan berjalan relatif baik; namun demikian, masih diperlukan pembenahan dalam aspek manajerial kepemimpinan. Keempat, pengendalian efektivitas supervisi kinerja guru dilakukan secara bertahap. Kelima, ide kreatif dan inovatif menekankan pada penguatan supervisi kinerja guru satuan pendidikan Madrasah Aliyah dan aplikasi e-Kinerja. Selain itu, pelaksanaan dan evaluasi supervisi kinerja guru telah dilaksanakan sesuai dengan Standar Operasional Prosedur (SOP) yang dikeluarkan oleh Kementerian Agama Republik Indonesia. Namun demikian, hasilnya masih belum efektif karena masalah berbagai keterbatasan sumber daya.
\end{abstract}

\begin{abstract}
A B S T R A C T
Observing the quality of education should include teachers as the frontline in education. Even a good curriculum and program will be meaningless if the teacher does not implement it responsibly and consistently. This study aims to analyze teacher performance supervision programs, organize teacher performance supervision programs, movement and leadership supervision of teacher performance, control the effectiveness of teacher performance supervision, and creative and innovative ideas in realizing the effectiveness of teacher performance supervision. This research uses a qualitative approach with the Case Study method. The method used to collect data is interviews, observation, and documentation. The instrument used to collect data is a questionnaire. Research subjects or research respondents were selected purposively. The technique used to analyze the data is descriptive qualitative analysis. The results of this study are, first, the planning program has not been implemented effectively due to the problem of limited resources. Second, the implementation of supervision has not been carried out optimally. Third, the movement and leadership went relatively well; however, improvements are still needed in the managerial aspects of leadership. Fourth, controlling the effectiveness of teacher performance supervision is carried out in stages. Fifth, creative and innovative ideas emphasize strengthening supervision of teacher performance in Madrasah Aliyah education units and e-Kinerja applications. In addition, the implementation and evaluation of teacher performance supervision have been carried out by the Standard Operating Procedures (SOP) issued by the Ministry of Religion of the Republic of Indonesia. However, the results are still not practical due to various resource constraints.
\end{abstract}

\section{INTRODUCTION}

The demand to improve the education quality implies schools' need to have educational human resources, both educators and other human resources, to perform optimally (Brookhart et al., 2016; Cabaleiro-Cerviño \& Vera, 2020; Effendi et al., 2020). It clearly results in the need to develop Human Resources in accordance with formal legal demands such as qualifications and competencies, as well as the demands of an increasingly competitive external environment in today's era of globalization (Alwis et al., 2020; Murdan, 2020; Udayani et al., 2021). This era demands high-quality human resources with creative 
attitudes and innovative performance, which are ready and able to face intense competition (C. Anwar et al., 2018; Lase, 2019; Meutia, 2021). Human resources development for educators/teachers significantly encourages teachers to improve their performance (Haji et al., 2020; Zaqiah et al., 2018).. This increase has implications for quantity and quality regarding how their performance is carried out. Moreover, in the context of current changes, innovative performance is an increasingly urgent demand for teachers to carry out their roles and duties as educators (Ahmad et al., 2020). Hence, they can produce creative and innovative graduates that can thrive in today's global era (Marmin et al., 2020). Therefore, an effort to continue teachers' performance development is vital to improve the education quality (Haji et al., 2020; Sudaryono et al., 2019). Thus, it requires appropriate performance management in the context of the school organization (Y. Liu et al., 2020; Olcum \& Titrek, 2015; Zaqiah et al., 2018). At the micro-technical level, teachers as an educator are educational leaders. They have a substantial impact on the classroom's learning process, and this leadership role will be reflected in how teachers carry out their roles and duties (Alwis et al., 2020; Lazarides et al., 2020). It implies that teachers' performance is a considerably determining factor for the learning/education quality, which will impact the education output quality after completing school (Chiva-Bartoll et al., 2021; Wachidi et al., 2020).

Teachers' performance is essentially a performance or work done by teachers in carrying out their duties as educators. The teachers' performance quality will significantly determine the quality of the educational outcomes (Derrington \& Campbell, 2018; Nurlaily et al., 2019). In fact, teachers have the most direct contact with students in the education/learning process at madrasah educational institutions (L. M. Anwar et al., 2019; Marmin et al., 2020). Therefore, devotion towards the teachers' performance development to keep improving becomes an urgent matter, especially concerning the increasing demands of the community related to the education quality (Hafid, 2017; Hoque et al., 2020). Furthermore, this, of course, will have implications on the teachers' performance quality. In carrying out their roles and duties in schools, especially in the learning process, teachers require development and variations towards a more innovative direction (Ihsan, 2019; Sulthon, 2017). Innovative teachers' performance is crucial for the successful implementation of educational innovations to improve the education/learning quality (Syar'i et al., 2020; Wene \& Muljani, 2020)

There are various problems to improve the education quality related to the teachers' condition in Indonesia. Research indicated that: First, there were a diverse teachers' abilities in the learning process and knowledge mastery, Second there was no accurate measurement to determine teachers' ability. Third, the guidance carried out did not reflect the needs. Fourth, inadequate teachers welfare (L. Liu et al., 2017; Rulitawati et al., 2020). If those issues are not resolved immediately, they will impact the low quality of education (Robertson-Kraft \& Zhang, 2018; Steinberg \& Kraft, 2017). The low quality of education is determined by several significant problems, among others (Hoque et al., 2020; Mukhtar et al., 2021). One of the characteristics of the education crisis in Indonesia is that teachers have not been able to show adequate performance. It indicates that teachers' performance has not been fully supported by an adequate degree of competency mastery. Therefore, a comprehensive effort to improve teacher competence is highly required (Zaqiah et al., 2018). In addition, the reseacrh found that teachers do not yet possess "expertise in the subject's content, pedagogical, didactic and methodical, personal and social skills, especially disciplined and motivated, teamwork among teachers, and other educational personnel". (Donaldson \& Mavrogordato, 2018; Yaumi et al., 2018).

The Government, in this case, the Ministry of National Education (Kemendiknas) and the Ministry of Religious Affairs, have actually made various efforts to solve the above problems, such as training to improve teachers' competence and research. Notwithstanding, in reality, there are still several fundamental problems that need to be resolved immediately, for example, the low quality of teachers in various types, ways, and levels of education, both in educational institutions managed by the Ministry of National Education and in educational institutions managed by the Ministry of Religious Affairs (Majid, 2016; Sanusi, 2020). Apart from teachers' professional ability, commitment, discipline, and motivation, it is essential to concern teachers' performance (Flores and Derrington 2017; Suriansyah and Effendi 2019). Teachers' performance is assumed to be good if the teacher has carried out elements consisting of high loyalty and commitment to teaching tasks, mastering and developing learning materials, discipline in teaching and other tasks, creativity in teaching implementation, collaboration with all school members, the leadership of becoming a student role model, a good personality, honesty, and being objective in guiding students, as well as responsibility for their duties. Thus, discussing teacher performance quality cannot be separated from the achievement of learning outcomes (Fitria, 2020; Schles \& Robertson, 2019). This is because teacher performance determines its success.

Hence, the success of achieving educational goals is not solely dependent on providing teaching programs. The program needs to be supported by motivation, management systems, education administration, and supervision (Aji Sofanudin et al., 2016; Hasibuan \& Yusuf, 2020). In this matter, the 
educational process's implementation can achieve optimal results if the Principal focuses more on the teacher. In this case, a teacher is the implementer of the educational program operationalization. Nevertheless, in practice, the teacher may develop innovations in carrying out their duties. In other words, innovative performance is essential (Fauzi, 2016; Nadhirin, 2018). Education supervisors must fully understand the problems faced by teachers in their working areas (Emilzoli et al., 2021; Hasibuan \& Yusuf, 2020). In general, there are seven indicators that indicate teachers' weak performance in carrying out teaching assignments, namely: Poor understanding of learning strategies, Lack of proficiency in class management, Low ability to conduct and utilize classroom action research, Low achievement motivation, 5. Lack of discipline, 6. Low professional commitment, and Low time management skills (Wene \& Muljani, 2020).

Teachers have a crucial role in improving the education quality in an educational institution. Teachers are an essential component in educational attainment. The roles and duties carried out by teachers are very substantial. The teacher's job is not only to teach but also to educate, guide, nurture, and lead the class (L. Liu et al., 2017; Marmin et al., 2020; Rulitawati et al., 2020). Other factors that cause low teacher professionalism are described as follows: First, There are still many teachers who do not fully pursue their profession. This is because some teachers work outside their working hours to fulfill their daily needs, so they do not have the opportunity to improve themselves, whether they are reading, writing, or even browsing the internet. Second, The absence of a standard for teacher professionalism as demanded in developed countries. Third, The possibility of private universities producing outrageous or semi-finished teachers without considering their output in the field results in many teachers who do not comply with their professional ethics. Fourth, Teachers lack the motivation to improve self-quality because teachers are unrequired to do research, unlike lecturers in universities (Fitria, 2020; Zaqiah et al., 2018). Owe to that matter, previous research stated that education is one of the primary keys in the development of quality human resources (Hasanah et al., 2020; Majid, 2016). To improve the education quality, it is significantly influenced by teachers' performance in the learning process. The teachers' performance will have implications for improving the learning quality. Teachers' performance is influenced by several factors, including competence, motivation, and commitment for the teacher as the prominent role.

Based on the background of the problems of teachers' performance at Madrasah Aliyah Negeri (State Islamic Senior High School), further researches should be taken into account related to; the teachers' performance supervision program; organizing program for teachers' performance supervision; movement and leadership of teachers' performance supervision; control of teacher performance supervision effectiveness; creative and innovative ideas in actualizing teachers' performance supervision effectiveness in MAN 2 Banjarmasin and MAN 3 Banjarmasin. The purpose of this study is to further examine the reasons that hinder the implementation of teacher performance supervision.

\section{METHODS}

This research employed a qualitative research method with a case study in MAN 2 Banjarmasin and MAN 3 Banjarmasin. This research aims to obtain information on teachers' performance supervision, movement and leadership of teachers' supervision leadership, control of teacher performance supervision effectiveness; creative and innovative ideas in actualizing teachers' performance supervision effectiveness in MAN 2 Banjarmasin and MAN 3 Banjarmasin. The data collection process refers to research that is often carried out on qualitative research methods. First, Interview. In-depth interviews were conducted on research subjects whose unit of analysis was the implementation and evaluation of teachers' performance supervision at Madrasah Aliyah MAN 2 Banjarmasin and MAN 3 Banjarmasin. Second, observation. This technique was employed to strengthen data that had been extracted from other techniques by observing the learning activities, the school's capacity, and infrastructure of MAN 2 and MAN 3 Banjarmasin directly. Third, documentation. The researchers analyzed documents in the form of SKP (Employee Performance Review), LAKIP (Government Institution's Performance Accountability Report), PKG (Teacher Performance Assessment), journals, supervision policy documents, quality/quality manuals, reports, madrasah performance achievements as well as documents and literature relevant to the research problem.

Research subjects or research respondents were selected purposively. The informants selected were people who had sufficient knowledge and experience related to the research problem. Such us; Head of Education Affairs, Regional Office of the Ministry of Religious Affairs, South Kalimantan Province. Head of the Teacher Affairs in the Education Affairs, Regional Office of the Ministry of Religious, South Kalimantan Province, Principal of Madrasah Aliyah Negeri 2 and Madrasah Aliyah Negeri 3 Banjarmasin. Assistant Principal of Curriculum Affairs at Madrasah Aliyah Negeri 2 and Madrasah Aliyah Negeri 3 Banjarmasin. Teachers of Madrasah Aliyah Negeri 2 and Madrasah Aliyah Negeri 3 Banjarmasin. The research location 
was carried out at the Regional Office of the Ministry of Religious Affairs of South Kalimantan Province, Madrasah Aliyah Negeri 2 and Madrasah Aliyah Negeri 3 Banjarmasin.

The data collection procedure is the most critical step in research because the primary purpose is to obtain data. The data analysis technique employed in this research was qualitative data analysis. The data analysis used various data that might have a relationship, then further analysis and thorough analysis were provided. The data analysis process was described as follows: First, Data Collection. The data obtained from interviews, observations, and documentation were recorded in field notes, consisting of two parts: descriptive and reflective. Descriptive notes recorded what the researchers saw, heard, witnessed, and experienced without the researcher's opinion and interpretation of the phenomenon is experienced. Meanwhile, reflective notes containing the researchers' impressions, comments, opinions, and interpretations of the findings obtained and constituted material for the data collection plan for the next stage. Second, Data Reduction. The data reduction activities carried out in this study include: recapping the results of interviews then observing the results of collecting documents related to the focus of the study. Third, Data Display: In this step, the researchers attempted to compile relevant data to be information that can be concluded and had a specific meaning. Fourth, Conclusion and Verification: It is the stage of drawing conclusions based on findings and data verification. The initial conclusions were still provisional and would change if strong evidence was obtained to support the next data collection stage.

\section{RESULT AND DISCUSSION}

\section{Results}

The results of interviews and observations obtained a description of the supervision planning program in MAN 2 Banjarmasin, starting from an understanding of the performance supervision urgency. It was carried out in collaboration between teachers, so they understood that their performance was their responsibility as accountability to Allah SWT. When a sense of responsibility arises from oneself, then supervision will grow better. This study also obtained that supervision was planned at the beginning of the school year and was running well. To support teacher performance supervision planning, it is necessary to realize that teacher's responsibility is worship. In human resource development, MAN 2 Banjarmasin continued to improve the quality of teaching and education personnel through various training, workshops, and seminars. The teaching and educational resources at MAN 2 Banjarmasin currently had 119 educators and education personnel with details of 54 civil servants and 55 non-civil servants. Meanwhile, the education level ratio was $40 \%$ of S-2 (Master degree) graduates and $45 \%$ of S- 1 (undergraduate) graduates, and $15 \%$ of high school graduates. Additionally, 49 educators and education staff had obtained Educator Certificates from the Ministry of Education and Ministry of Religious Affairs.

The findings of this study were related to the planning of teacher performance supervision of MAN 2 Banjarmasin: the achievement of the vision, mission, and achievement of the teaching and learning program. Teachers could plan teaching and learning programs according to the calendar and syllabus. Teachers could also implement teaching and learning activities according to the plans that have been made. Moreover, teachers could improve the quality of teaching and learning activities. In addition, the purpose of planning the teachers' performance supervision in MAN 2 Banjarmasin was to obtain information and documentation. The material to be concerned for teachers' performance supervision of MAN 2 Banjarmasin was teachers' capability to achieve the madrasah's vision and mission. Teachers were able to contribute optimally to improve the quality of student learning. In addition, teachers could enrich and improve the quality of their performance every year. Furthermore, the material for supervision includes planning for teaching and learning activities, implementing teaching and learning activities, additional tasks that are the teacher's responsibility, and teacher competence (pedagogy, personality, social, professionalism). This study also identified the material compiled in the teachers' performance planning of MAN2 Banjarmasin, as follows: First, Determining teachers' contribution to achieve educational goals in Madrasah by doing the job well. Second, Determining cooperation between madrasah teachers and Principal to work together to maintain, improve, or develop teacher's performance. Third, Establishing indicators of work performance that will be measured by the Principal of the madrasah. Fourth, Analyzing and identifying various performance barriers and seeking solutions and efforts to overcome them.

Based on the results of document studies and interviews, indicators of the success of teacher performance supervision planning can be seen through the SKP (employee performance review). The SKP value was partially obtained from the PK Guru (Teachers' Performance Assessment) and based on the document available in the madrasah. In addition, the success of teachers' performance was also measured by the learning process/guidance for students, self-development as an educator, scientific publication/innovative work as a teacher, and other supporting elements. This study also indicated that teachers' performance in MAN 2 Banjarmasin was a success indicator of teachers' performance. It can be seen through their disciplines, such as coming to the classroom on time, and their material mastery, 
student's ability to absorb the material, and teachers' academic achievement. These are all success indicators of teachers' performance in MAN 2 Banjarmasin.

At the beginning of the school year, the Madrasah formed a team to carry out supervision, called PKG, occupied by the Assistance Principal of the Curriculum Affairs or senior teachers. Senior teachers supervised teachers who are in the same position or under their position. One supervisor teacher would supervise 5 or 6 peer teachers. Teachers' performance supervision was established according to a decree issued by the Principal of the Madrasah. This team consisted of the Principal of Madrasah, Assistant Principal of Curriculum Affairs, and senior teachers or teachers with the rank of class IV/a. This team's main task was to assess teachers, as outlined in the PKG document, with an assessment period of 6 months or twice a year, namely the January-June and July-December periods. Based on the interview results, it was obtained that the supervision process was carried out for one year, and the formative PKG was carried out at the beginning of the fiscal/academic year and only for the first year for new teachers or teacher transfers. Furthermore, summative PKG was held eight weeks before the end of the fiscal year. It was recommended that the PKG report be completed in mid-December because it would be used as an assessment material for the Employee Performance Review Achievement (CSKP). Teacher Performance Assessment with one semester assessment period was intended for teachers who lack a few credit points for promotion. Thus, these teachers are obliged to do additional assignments for one semester (namely, school principal, deputy, head of the librarian, head of the laboratory/workshop, head of the expertise program).

In coordinating and communicating teachers' performance supervision, MAN 2 Banjarmasin collaborated with the Educational Sector of Madrasah, teachers, and the Principal of Madrasah, the head of Madrasah education sector, and the head of teachers. It aimed to disseminate information on integrating and coordinating teachers' performance supervision to the authorized parties. Hence, it could be used as a reference in making policy for teachers' performance improvement. Furthermore, the research also found out the implementation of organizing the resources capability supervision. As a matter of fact, MAN 2 Banjarmasin had qualified teachers based on the requirements, or even higher than that. This condition indicated that MAN 2 teachers had adequate capabilities in performing their tasks. From the interview with the participants, it was obtained that the efforts to improve Human Resources of MAN 2 Banjarmasin to support teachers' performance supervision are as follows: Education, training, workshop, and seminar, Position Promotion, and Staff Education. In addition, the interview results also indicated some efforts to improve teachers' performance, namely: 1) welcoming teacher properly; 2) giving new teaching assignments based on the teachers' expertise and skill; 3) forming a teacher working group in the field of study and Teachers Professional Development Forum (MGMP) as a place to discuss planning and problems solving in class; 4) carrying out administrative and teachers' academic supervision as a reference for improvement and determining policies; 5) providing guidance for teachers' administrative, academic, and career; 6) providing opportunities for teachers to take part in a training held at schools, districts, provinces, and at the national level; 7) giving rewards to excellent teachers and giving punishment to lazy and troublesome teachers; 8) giving additional assignments to teachers, and 9) forming kinship among teachers and having a regular gathering in teachers' house.

The culture of monitoring organization toward teachers' performance in MAN 2 Banjarmasin was exemplification and discipline. Based on the interview result with the participants, the organizational culture implemented in MAN 2 Banjarmasin could significantly improve teachers' performance supervision. In addition, organization performance culture was also conducted by following headmaster and teachers' exemplification. Discipline teachers usually had good performance because they had good time management and performance management. This research also discovered an organizational culture applied in MAN 2 Banjarmasin. Madrasah organization culture was established and upheld together with the founder of the educational institution, the Principal of madrasah, teachers, and entire elements in madrasah. Madrasah, as an Islamic Education institution concerning Islamic-based education development, strengthens its organization in a positive culture. Hence, it is expected that the learning will run effectively to generate high-quality output. The movement allocating resources and procedures in teachers' performance supervision in MAN 2 Banjarmasin was conducted by regular performance evaluation. Performance evaluation was usually carried out in the monthly meeting. Thus, performance achievement could be revealed early. Moreover, the teaching and learning activity's supervision was also regularly conducted through academic supervision, either conducted by the Principal or supervisor of the madrasah. The procedure set out was applied based on resources of teachers' performance monitoring of MAN 2 Banjarmasin.

In the implementation of teachers' performance supervision in MAN 2 Banjarmasin, the leadership function was carried out by full coordination. The Principal of the madrasah classified, delivered, provided information, provided input, and provided instructions to teachers. The results of the study indicated that the implementation of performance supervision of MAN 2 Banjarmasin ran well. If the leader were timedisciplined, the subordinates would follow it, and vice versa. If the leader could not give an excellent example to his subordinates, discipline could not be achieved. The effectiveness of leadership in improving the subordinates' performance should be supported by the ability to provide awareness to subordinates 
that the duties and responsibilities of their work are not only supervised by their supervisors but also under Allah SWT. The Principal of the madrasah played a crucial role in teachers' performance supervision. The Principal was the one who had the strategy in improving teachers' performance. In addition, the attitude and behavior of the Principal of the madrasah significantly determined the leadership effectiveness. The role of the Principal of the madrasah was considerably influential in teachers' performance supervision. It proves from the teachers' discipline, learning target achievement, and madrasah vision and mission achievement.

Based on the interview and document study, basic policies as the guideline in implementing teachers' performance supervision of MAN 2 Banjarmasin were as follows: Constitution Number 20 of 2003 concerning the National Education System, Constitution of Republic of Indonesia Number 14 of 2005 concerning Teachers and Lecturers, Government Regulation Number 19 of 2005 concerning National Education Standards. Government Regulation Number 74 of 2008 concerning Teachers, Regulation of the Minister of National Education Number 16 of 2007 concerning Academic Qualification Standards and Teacher Competencies, Regulation of the Minister of National Education Number 18 of 2007 concerning Teacher Certification in Position, Government Regulation of Republic of Indonesia No. 19 of 2017 concerning Teachers, Government Regulation of Republic of Indonesia No. 74 of 2008 concerning Teachers and Decree of the Ministry of National Education No. 35 of 2010 concerning Technical Guidelines for the Implementation of Teacher Functional Positions and Credit Figures. Based on the interview conducted with the informant, the problems faced in the implementation of teachers' performance supervision were teachers did not have the same skill in finishing a task. Meanwhile, teachers must be scored as good regardless of the real condition. If teachers are not scored as good, it will affect their allowance.

This study found out that controlling the effectiveness of teachers' performance was carried out in stages. The Principal created a performance monitoring program with a variety of instruments. Then, the instrument was carried out individually by each teacher under the Principal's supervision and assisted by the head of curriculum affairs and peers. If there were things that deviate or not on the right track, individual coaching could be carried out. It could be oral coaching or written coaching. The Principal of the madrasah and the vice principal supervised teachers' performance by peeking. It was usually done in the morning before the pandemic. Administrative supervision at MAN 2 Banjarmasin was highly concerned. Especially at the beginning of the semester, teachers were encouraged to complete the administration. Then during the pandemic, they conducted students' polling regarding teachers' performance. The Principal of the madrasah's role in controlling the effectiveness of teachers' performance supervision was carrying out duties according to his function. He then reported it through the vice principal of academic affairs. Performance supervision was also carried out through a set of administrative tools, but what really needed to be emphasized was the awareness of individuals, groups, and all employees of their respective responsibilities and duties that must always be put forward.

Based on the research result, the following ways were to actualize the effectiveness of teachers' performance of MAN 2 Banjarmasin. First, Advising that the tasks and responsibilities of teachers would be accounted for Allah SWT. Second, The Principal and the Vice-Principal of Madrasah were role models for the subordinates. Third, Giving awards for those who worked excellently and giving reprimand or even punishment for those who broke the rule. Fourth, Authorizing work units of the teachers' team in MAN 2 Banjarmasin to optimize the function and role in improving the performance supervision. The most crucial thing to improve the effectiveness of teachers' performance supervision was by approaching teachers when they were in trouble. In addition, a religious approach was required to touch teachers' hearts. Presently, teachers' attendance checking is online. Meanwhile, before this pandemic, teachers filled their attendance by fingerprint when they come to school. The most important thing was teachers. Based on the results of interviews, observations, and document studies, it was discovered that the planning of teachers' performance supervision in MAN 3 Banjarmasin refers to the Regulation of the Minister of State for Administrative Reform and Bureaucratic Reform Number 16 of 2009. It states that Teacher Performance Assessment is an assessment carried out on each item of the teacher's main task for career development, rank, and position. The purpose of monitoring supervision and performance reports was to measure teachers' competence regarding teaching skills and find out teachers' daily activities. Meanwhile, other information mentions that teachers' performance supervision aimed to generate teachers who were ready to teach, having honorable behavior, and being disciplined. Furthermore, the research results identified the planning objectives of teachers' performance supervision, among others: 1) Underlying policies regarding teachers' promotion and career along with the rewards that should be earned; 2) As an indicator to determine the level of competence; 3 ) Improving teacher and school performance including efficiency and effectiveness. 4) Providing guarantees always to carry out their duties and responsibilities and be positive in learning to support their students' achievement. 5) Providing a foundation for the implementation of a sustainable professional program (PKB), and 6) Being a basis for determining the effectiveness of teachers' performance.

According to the results of interviews, observation, and document study, it was identified that the supervision material was the learning process, learning design, syllabus, journals, teaching materials, 
semester programs, and annual programs. The supervision material regarding daily performance reported in the form of paper was attendance, scheduled teaching activities, conducting discussions/coordination with fellow teachers. Additionally, the achievement results that had been carried out, such as; First, Class supervision material including: during the learning process, lesson plans, syllabus, journals, semester programs, and annual programs. Second, Supervisory material about daily performance reports filled out online by teachers containing teacher activities on that day. Third, Supervision material consisting of the syllabus, lesson plans, learning materials, journals, teaching and learning activities, semester programs, and annual programs. Fourth, Supervision material regarding daily performance reports in the form of attendance, scheduled teaching activities, conducting discussions/coordination with peer teachers, and the achievement results that have been carried out. Fifth, Supervision material specifically concerns the teachers' competence, including pedagogical competence, personality, social and professional. According to participant information, a success indicator of supervision means being able to carry out learning activities properly to improve the education quality of the madrasah. Success indicator of performance report is the implementation of activities or assignments given to the teacher properly. Success indicator means teachers consciously conduct learning activities every day. Supervision success indicator refers to the ability to carry out the learning process properly following the planned learning objectives to improve the education quality in the madrasah. The performance report's success indicator means the activities or assignments given to the teacher council are adequately accomplished.

In organizing this program, a supervision schedule was arranged from the daily performance through the e-Kinerja application. Then, the Principal, the vice-principal, and senior teachers conducted supervision. The job division was done based on the learning schedule and assignment task decided by the curriculum affairs, and it was approved by the Principal of the madrasah. The supervision design was the supervisors' team, consisting of the Principal of madrasah, the vice-principal of curriculum affairs, and senior teachers. It also appointed the administration staff to coordinate the collection and ask for the Principal's approval as well as evaluate teachers' performance. The supervision ratio conducted by the senior teachers to other teachers was 5 to 10 teachers supervised by one senior teacher. Further, the Principal of Madrasah would issue an assignment task for the supervisors. Integration and coordination of the supervision of madrasah principals toward teachers were conducted by forming a management team led by the head of the unit. Supervision was led by the head of the curriculum. Meanwhile, the performance reports were led by the head of administration staff. The results of this research found out that integration and coordination of teachers' performance were implemented by coordinating with the Principal of Madrasah through a coordination meeting with the Principal of Madrasah Education at the Ministry of Religion Office of Banjarmasin City. This coordination was to know the conditions and problems faced to conduct follow-up or problem-solving.

The development of organizational capacity was carried out excellently because competent employees led it. Besides, teachers could follow it easily. $80 \%$ of teachers could carry out the performance determined by the principal madrasah, and $20 \%$ of teachers still needed guidance to carry out the predetermined performance. In addition, the development of organizational capabilities was carried out very well because it was led by competent employees to follow it. Most of them were able to perform well, and a few employees still needed guidance. Supervision culture refers to supervision carried out every year and daily performance reports in the form of papers that were collected every month. Further, supervision culture means regular supervision and a daily performance report of teachers submitted to the Principal of Madrasah once a month. Additionally, supervision culture was in the form of supervision and performance reports. Movement and leadership were conducted through resource allocation, implementation procedures adjustment with resources used in teachers' performance supervision. Based on the study results, the leadership mobilization was carried out by coordinating with the Assistant Principal of Academics, Student Affairs, Public Relations, Infrastructure, Head of Administration Staffs, and Head of Committee related to performance improvement and appreciation for teachers performing their duties well. The appreciation was in the form of allowances in accordance with regulations.

Based on the interview result, the Principal of the Madrasah functions to control and evaluate the teachers' performance results. The Principal recorded the supervision result and evaluated it with the teacher council. Besides, the teacher checked the performance reports and followed up on weaknesses and strengths. The Principal of Madrasah also functioned to control and evaluate the results of teacher performance and lead the implementation of teachers' performance supervision. The result of the research indicated that the Principal of Madrasah had a role as a policy maker related to education quality improvement and the allowance payment. It was expected to encourage teachers to be more disciplined in carrying out their duties properly. The Principal of Madrasah made a schedule of supervision. Furthermore, the Principal of Madrasah issued assignment letters, formed work teams, and provided performance incentives based on the regulations. The Principal of Madrasah authorized the supervisor team to carry out supervision through the issuance of an Assignment Decree consisting of Vice-Principal of Madrasah and senior teachers. In regulating the effectiveness of teachers' performance supervision, MAN 3 Banjarmasin collaborated with the Teachers Department of the Ministry of Religious Affairs of the Regional Office 
through the Madrasah Education Department to monitor the development of potential teachers and education personnel. The interview results identified the problems in the implementation: teachers who were not fully responsible and had different views regarding the policies. In other words, different understanding and views among teachers were the problems in this implementation. Sometimes, a feeling of reluctance and subjectivity still mixed the supervision.

Effectiveness control of teachers' performance supervision was carried out by scheduling the supervision and forming supervisor teams consisting of the Assistant Principal of curriculum affairs and senior teachers to supervise the teacher council. In addition, the administration team collected data and reminded teachers to collect daily performance reports on paper. From the results of interviews and document studies, the supervision team gave teachers their supervision schedules. Furthermore, for the performance reports, the administration team would remind and control the performance report collection. Supervision was carried out according to schedule. Meanwhile, the functions of the Teacher Affairs Department were to monitor teachers' development in Vocational Madrasah and Madrasah Aliyah. On the other hand, the teacher's assessment was carried out by the Principal of Madrasah as the direct supervisor. Thus, regular coordination with the Principal of Madrasah was required to control the implementation of teachers' performance supervision. The Principal played a significant role in providing the policy, supervise, and evaluate teachers' performance. Additionally, the supervision function and teachers' performance assessment was conducted by the Principal of the madrasah. Therefore, teachers conducted the coordination functions with the Principal as follows: 1) Direct or indirect coordination with the Principal of madrasah, and 2) Direct coordination was done through a meeting of the Principal's working teams. Indirect coordination was done through information from the Board of Religious Affairs of Regency/City. In addition, learning activities in MAN 3 Banjarmasin during this pandemic are conducted by online learning. The madrasah e-learning was issued by the Ministry of Religious Affairs. In fact, the features of madrasah elearning are relatively good. The examples of these advanced features are timeline as a forum for discussion, student attendance, teacher attendance, and teaching material. The teaching material feature made it students easier to get material references. The results of this study also found out teachers who were not disciplined when the Principal was away. These teachers did not carry out their duties optimally. However, the Principal still supervised teachers by asking trusted students or teachers to be an informant. Thus, the Principal would know whether there were teachers skipping the class or coming late.

The creative and innovative ideas to actualize the performance effectiveness were by using electronic absence checking (fingerprint), website application on the performance report (e-Kinerja), and website application related to e-learning. The steps taken to have effective supervision required teachers to do electronic attendance checking to have more accurate time. In addition, teachers used the $e$-Kinerja application to compile daily activities and printed them out to be submitted to the administration staff. Besides, teachers used e-learning applications to teach during the current pandemic. Furthermore, the results of interviews, observations, and document studies indicated that this Covid-19 pandemic did not reduce control over teachers' performance in carrying out their duties despite the online teaching activities. Madrasah Aliyah Negeri 3 Banjarmasin applied an emergency curriculum, where teachers took turns to go to school to keep providing educational services. Teachers' attendance list was conducted online. Even, there was a learning evaluation every month to assess the teaching and learning process.

\section{Discussion}

Teachers' performance supervision of MAN 2 Banjarmasin and MAN 3 Banjarmasin had been applied in the form of the Supervisor Team (PK). It functioned to supervise teachers' performance (Anom, 2020; Chandra, 2018; McGarr \& Gallchóir, 2021). It could positively impact teachers' performance improvement if it were conducted seriously based on the stipulation and regulation (Hoque et al., 2020; Ningrat et al., 2020; Sitasih, 2020). Hence, performance evaluation carried out by supervisors of MAN 2 Banjarmasin and MAN 3 Banjarmasin had run effectively. Teachers' performance supervision of MAN 2 Banjarmasin and MAN 3 Banjarmasin had been applied in the form of the Supervisor Team (PK). It functioned to supervise teachers' performance. It could positively impact teachers' performance improvement if it were conducted seriously based on the stipulation and regulation (Ardana et al., 2020; Nugroho \& Hendayana, 2011). Hence, performance evaluation carried out by supervisors of MAN 2 Banjarmasin and MAN 3 Banjarmasin had run effectively.

The movement and leadership of teachers' performance supervision could directly impact efforts to improve teachers' performance with the strategic role of leadership in MAN 2 Banjarmasin and MAN 3 Banjarmasin. The strategic role of leadership in Madrasah Aliyah included managerial abilities in mobilizing teacher resources (Nadhirin, 2018; Tambak \& Sukenti, 2020). As a matter of fact, effective leadership and efforts to mobilize teaching staff resources would impact teachers' performance in MAN 2 Banjarmasin and MAN 3 Banjarmasin. In the scope of education management, controlling was a strategic step to ensure whether the supervision process was conducted under the planned objectives and the effectiveness of teachers' performance supervision (Chandra, 2018; Sumarsono et al., 2019). Therefore, control had a 
crucial role in the learning process, especially in MAN 2 Banjarmasin and MAN 3 Banjarmasin. Creative and innovative ideas emphasized the importance of Supervisor Teams in Madrasah Aliyah education units and e-Kinerja implementation.

\section{CONCLUSION}

The implementation and evaluation of teachers' performance supervision of MAN 2 Banjarmasin and MAN 3 Banjarmasin was relatively suitable with the Standard Operating Procedure (SOP) issued by the Ministry of Religious Affairs of the Republic of Indonesia. The program of teachers' performance supervision in MAN 2 Banjarmasin and MAN 3 Banjarmasin was gradually carried out. It started from the level of the Ministry of Religious Affairs of the Republic of Indonesia to the level of academic units. Teachers' performance supervision of MAN 2 Banjarmasin and MAN 3 Banjarmasin had been applied in the form of the Supervisor Team (PK). The strategic role of leadership in Madrasah Aliyah included managerial abilities in mobilizing teacher resources. In the scope of education management, controlling was a strategic step to ensure whether the supervision process was conducted under the planned objectives and the effectiveness of teachers' performance supervision.

\section{REFERENCES}

Ahmad, A., Gistituati, N., \& Rusdinal. (2020). Management of the Madrasah Principal to Get "A" Accreditation in MTSN 1 Sijunjung. Proceedings of the 2nd International Conference Innovation, 504(ICoIE), 185188. https://doi.org/10.2991/assehr.k.201209.216.

Aji Sofanudin, Rokhman, F., Wasino, \& Rusdarti. (2016). Quality-Oriented Management of Educational Innovation at Madrasah Ibtidaiyah. Journal of Education and Practice, 7(27), 176-180. https://doi.org/10.12928/ijemi.v2i1.3007.

Alwis, A., Z., S. M., Effendi, M., \& Jama, J. (2020). Developing Academic Supervision Model To Improve Islamic Education (PAI) Teachers' Performance At Madrasah Aliyah (Islamic Senior High Schools). Digital Press Social Sciences and Humanities, 6, 00014. https://doi.org/10.29037/digitalpress. 46379.

Anom, A. (2020). Supervisi Edukatif Untuk Meningkatkan Kemampuan Guru dalam Pembelajaran di SD Gusti . Jurnal Ilmiah Sekolah Dasar, 4(2). https://doi.org/10.23887/jisd.v4i2.25443.

Anwar, C., Saregar, A., Hasanah, U., \& Widayanti. (2018). The Effectiveness of Islamic Religious Education inthe Universities: The Effects on the Students' Characters in the Era of Industry 4.0. Tadris: Jurnal Keguruan Dan Ilmu Tarbiyah, 3(1), 77-87. https://doi.org/10.24042/tadris.v3i1.2162.

Anwar, L. M., Jufri, A. W., \& Muhaimi, L. (2019). Application of Madrasah Based Management in Improving the Quality of Aliyah Madrasah Education. International Journal of Multicultural and Multireligious Understanding, 6(5), 257. https://doi.org/10.18415/ijmmu.v6i5.1086.

Ardana, P., Yudana, I. M., \& Divayana, D. G. H. (2020). Kontribusi Sertifikasi Guru, Motivasi Kerja Dan Supervisi Akademik Kepala Sekolah Terhadap Kinerja Guru. Jurnal Administrasi Pendidikan Indonesia, 11(1), 44-55. https://doi.org/10.23887/japi.v11i1.3349.

Brookhart, S. M., Guskey, T. R., Bowers, A. J., McMillan, J. H., Smith, J. K., Smith, L. F., Stevens, M. T., \& Welsh, M. E. (2016). A Century of Grading Research: Meaning and Value in the Most Common Educational Measure. Review of Educational Research, 84(4). https://doi.org/10.3102/0034654316672069.

Cabaleiro-Cerviño, G., \& Vera, C. (2020). The Impact of Educational Technologies in Higher Education. GIST - Education and Learning Research Journal, 20,155-169. https://doi.org/10.26817/16925777.711.

Chandra. (2018). Meningkatnya Kinerja Guru Dalam Pembelajaran Di Kelas Melalui Supervisi Edukatif Kolaboratif Secara Sistematis Dan Terjadwal. Jurnal Pendidikan Tambusai, 2(3). https://doi.org/10.31004/jptam.v2i3.192.

Chiva-Bartoll, O., Ruiz-Montero, P. J., Olivencia, J. J. L., \& Grönlund, H. (2021). The effects of service-learning on physical education teacher education: A case study on the border between Africa and Europe. SAGE Journals. https://doi.org/10.1177/1356336X211007156.

Derrington, M. L., \& Campbell, J. W. (2018). High-stakes teacher evaluation policy: US principals' perspectives and variations in practice. Teachers and Teaching, 24(3), 246-262. https: //doi.org/10.1080/13540602.2017.1421164.

Donaldson, M., \& Mavrogordato, M. (2018). Principals and teacher evaluation. Journal of Educational Administration, 56(6), 586-601. https://doi.org/10.1108/JEA-08-2017-0100.

Effendi, R., Lian, B., \& Sari, A. P. (2020). Principal Leadership Policy in Improving Instructional Quality. International Journal of Progressive Sciences and Technologies (IJPSAT), 368-375. https: //doi.org/10.52155/ijpsat.v22.1.2086. 
Emilzoli, M., Ali, M., \& Rusman. (2021). Perceptions, attitudes and lifestyles of students of Madrasah Ibtidaiyah Teacher Education Study Program about education for sustainable development. IOP Conference Series: Earth and Environmental Science, 739(1). https://doi.org/10.1088/17551315/739/1/012058.

Fauzi, A. (2016). The Management of Teachers' Empowerment of State Madrasah Aliyah in Banten Province. Higher Education Studies, 6(2), 99. https://doi.org/10.5539/hes.v6n2p99.

Fitria, H. (2020). The Implementation of Class Supervision and Its Positive Impact. Journal of Social Work and Science Education, 1(2), 146-160. https://doi.org/10.52690/jswse.v1i2.43.

Flores, M. A., \& Derrington, M. L. (2017). School principals' views of teacher evaluation policy: lessons learned from two empirical studies. International Journal of Leadership in Education, 20(4), 416431. https://doi.org/10.1080/13603124.2015.1094144.

Hafid, M. (2017). Pengaruh Motivasi dan Kompetensi Guru Terhadap Kinerja Guru Sekolah dan Madrasah di Lingkungan Pondok Pesantren Salafiyah Syafi'iyah Sukorejo. Jurnal Pendidikan Islam Indonesia, 1(2), 293-314. https://doi.org/10.35316/jpii.v1i2.55.

Haji, S., Lian, B., \& Fitriani, Y. (2020). An Evaluation Of School Operational Fund Program. International Journal of Educational Review, 2(2), 212-221. https://doi.org/10.33369/ijer.v2i2.11001.

Hasanah, A., Nonitasari, I., \& Habibah, H. (2020). Madrasah Head Policy in Improving the Quality of Teacher Profession. International Journal for Educational and Vocational Studies, 2(12), 1024-1029. https://doi.org/10.29103/ijevs.v2i12.3017.

Hasibuan, L., \& Yusuf, M. (2020). Education Personnel Management Model for Improving the Performance of Public Madrasah Aliyah Teachers in Jambi Province. International Journal of Progressive Sciences and Technologies (IJPSAT), 2019, 393-401. https://doi.org/10.52155/ijpsat.v23.2.2346.

Hoque, K. E., Bt Kenayathulla, H. B., D/O Subramaniam, M. V., \& Islam, R. (2020). Relationships Between Supervision and Teachers' Performance and Attitude in Secondary Schools in Malaysia. SAGE Open, 10(2), 215824402092550. https://doi.org/10.1177/2158244020925501.

Ihsan, I. (2019). Pesantren-Based Madrasah: Curriculum Implementation Model and Integrative Learning. Media Dialektika Ilmu Islam, 13(2), 401. https://doi.org/10.21043/addin.v13i2.8078.

Lase, D. (2019). Education and Industrial Revolution 4.0. Handayani Journal PGSD FIP Unimed, 10(1), 4862. https://doi.org/10.24114/jh.v10i1.14138.

Lazarides, R., Warner, L. M., Lazarides, R., \& Warner, L. M. (2020). Teacher Self-Efficacy. In Oxford Research Encyclopedia of Education. Oxford University Press. https://doi.org/10.1093/acrefore/9780190264093.013.890.

Liu, L., Xu, B., \& Ju, Y. (2017). Addition of spironolactone in patients with resistant hypertension: A metaanalysis of randomized controlled trials. Clinical and Experimental Hypertension, 39(3), 257-263. https://doi.org/10.1080/10641963.2016.1246564.

Liu, Y., Bellibaş, M. Ş., \& Gümüş, S. (2020). The effect of instructional leadership and distributed leadership on teacher self-efficacy and job satisfaction: Mediating roles of supportive school culture and teacher collaboration. Educational Management Administration and Leadership, 1-24. https://doi.org/10.1177/1741143220910438.

Majid, A. (2016). Strategi Pembelajaran. PT Remaja. Rosdakarya.

Marmin, M., Koderi, K., Muin, J. A., Fahri, J., \& Imam, S. (2020). The Effectiveness of Supervision Program At Madrasah Aliyah in Pesawaran Regency. Educational Management, 9(2), 248-257.

McGarr, O., \& Gallchóir, C. Ó. (2021). Examining supervising field instructors' reporting and assessment of technology use by pre-service teachers on school placement. Computers \& Education, 146. https://doi.org/10.1016/j.compedu.2019.103753.

Meutia, M. (2021). Teacher Strategies in Improving the Quality of Students at MTs 2 Medan Country. International Journal of Education, Social Studies, And Management (IJESSM), 1(1), 49-57. https://doi.org/10.52121/ijessm.v1i1.7.

Mukhtar, El-Widdah, M., \& Padli, M. (2021). The Impression of Kiai's Leadership In Managing Islamic Boarding Schools. International Journal of Educational Review, 3(1). https://doi.org/https://doi.org/10.33369/ijer.v3i1.11689.

Murdan, M. (2020). Pesantren's Traditions in Preparing Human Resources (Santri) at Ibnul Amin Pamangkih and Rasyidiyah Khalidiyah Amuntai Pesantren. Ta'dib: Jurnal Pendidikan Islam, 25(2). https://doi.org/10.19109/tjie.v25i2.6738.

Nadhirin, N. (2018). Teaching Supervision of Madrasah Headmaster Based on Pesantren Culture. QIJIS (Qudus International Journal of Islamic Studies), 5(2). https://doi.org/10.21043/qijis.v5i2.3122.

Ningrat, S. P., Agung, A. A. G., \& Yudana, I. M. (2020). Kontribusi Etos Kerja, Motivasi Kerja, Disiplin Kerja dan Supervisi Akademik Terhadap Kinerja Guru Sd Gugus VII Kecamatan Mengwi. Jurnal Administrasi Pendidikan Indonesia, 3(1), 54-63. https://doi.org/10.23887/japi.v11i1.3169. 
Nugroho, L. A., \& Hendayana, S. (2011). Penerapan Lesson Study Berbasis Sekolah Untuk Melaksanakan Supervisi Akademik Pembelajaran Fisika Di Sma1. Jurnal Penelitian Pembelajaran Matematika, 2(1). https://doi.org/10.26877/jp2f.v2i1/April.124.

Nurlaily, V. A., Soegiyanto, H., \& Usodo, B. (2019). Elementary school teacher's obstacles in the implementation of problem-based learning model in mathematics learning. Journal on Mathematics Education, 10(2), 229-238. https://doi.org/10.22342/jme.10.2.5386.229-238.

Olcum, D., \& Titrek, O. (2015). The effect of school administrators' decision-making styles on teacher job satisfaction. Procedia - Socialand Behavioral Sciences, 197, 1936-1946. https://doi.org/10.1016/j.sbspro.2015. 07.575.

Robertson-Kraft, C., \& Zhang, R. S. (2018). Keeping Great Teachers: A Case Study on the Impact and Implementation of a Pilot Teacher Evaluation System. Educational Policy, 32(3), 363-394. https://doi.org/10.1177/0895904816637685.

Rulitawati, Ritonga, A. H., \& Hasibuan, L. (2020). Management Performance Model of High School Teachers of Muhammadiyah in South Sumatera. International Journal of Educational Review, 2(3). https://doi.org/https://doi.org/10.33369/ijer.v2i1.10381.

Sanusi, H. P. (2020). Madrasah Quality Improvement Evaluation Strategic Management Based. International Journal of Nusantara Islam, 8(2), 137-145. https://doi.org/10.15575/ijni.v8i2.10510.

Schles, R. A., \& Robertson, R. E. (2019). The Role of Performance Feedback and Implementation of EvidenceBased Practices for Preservice Special Education Teachers and Student Outcomes: A Review of the Literature. Teacher Education and Special Education: The Journal of the Teacher Education Division of the Council for Exceptional Children, 42(1), 36-48. https://doi.org/10.1177/0888406417736571.

Sitasih, D. K. (2020). Supervisi Akademik untuk Meningkatka Kompetensi Guru Dalam Proses Pembelajaran di SD. Jurnal Ilmiah Sekolah Dasar, 4(1). https://doi.org/10.23887/jisd.v4i2.25461.

Steinberg, M. P., \& Kraft, M. A. (2017). The Sensitivity of Teacher Performance Ratings to the Design of Teacher Evaluation Systems. Educational Researcher, 46(7), 378-396. https://doi.org/10.3102/0013189X17726752.

Sudaryono, Lutfiani, N., Suseno, \& Aini, Q. (2019). Empirical Study of Research Performance Leading to Education 4.0 using the iLearning Method. International Journal of Advanced Trends in Computer Science and Engineering, 8(1). https://doi.org/10.30534/ijatcse/2019/4681.52019.

Sulthon, S. (2017). Pembelajaran IPA Yang Efektif dan Menyenangkan Bagi Siswa Madrasah Ibtidaiyah (MI). ELEMENTARY: Islamic Teacher Journal, 4(1). https://doi.org/10.21043/elementary.v4i1.1969.

Sumarsono, R. B., Imron, A., Wiyono, B. B., \& Arifin, I. (2019). Strategi Kepala Sekolah Dalam Mengoptimalkan Partisipasi Orangtua Untuk Meningkatkan Kualitas Sekolah. JMSP: Jurnal Manajemen Dan Supervisi Pendidikan, 4(1). https://doi.org/10.17977/um025v4i12019p007.

Suriansyah, A., \& Effendi, R. (2019). Effect of Academic Supervision and School Culture on Teacher's Teaching Quality in Public Islamic Senior High School Banjarmasin. Journal of K6, Education, and Management, 2(2), 126-132. https://doi.org/10.11594/jk6em.02.02.07.

Syar'i, A., Akrim, A., \& Hamdanah. (2020). The Development of Madrasa Education in Indonesia. Revista Argentina de Clínica Psicológica, 29(4), 513. https://doi.org/10.24205/03276716.2020.858.

Tambak, S., \& Sukenti, D. (2020). Pengembangan Profesionalisme Guru Madrasah dengan Penguatan Konsep Khalifah. Hayula: Indonesian Journal of Multidisciplinary Islamic Studies, 4(1). https://doi.org/10.21831/cp.v39i1.26001.

Udayani, N. K. R. T. K., Wibawa, I. M. C., \& Rati, N. W. (2021). Development Of E-Comic Learning Media On The Topic Of The Human Digestive System. Journal of Education Technology, 5(3), 472-481. https://doi.org/10.23887/jet.v5i3.34732.

Wachidi, W., Rodgers, A., \& Tumanov, D. Y. (2020). Professional Competence Understanding Level of Elementary School in Implementing Curriculum 2013. International Journal of Educational Review, 2(1), 99-105. https://doi.org/10.33369/ijer.v2i1.10642.

Wene, I. W. O. A., \& Muljani, R. (2020). English Teacher s ' Performance Evaluation as a Means for Their Professional Developments. Indonesian Research Journal in Education, 4(2), 483-497. https://doi.org/10.22437/irje.v4i2.10167.

Yaumi, M., Sirate, S. F. S., \& Patak, A. A. (2018). Investigating Multiple Intelligence-Based Instructions Approach on Performance Improvement of Indonesian Elementary Madrasah Teachers. SAGE Open, 8(4). https://doi.org/10.1177/2158244018809216.

Zaqiah, Q. Y., Suhendar, D., \& Maryani, N. (2018). Evaluation of Teacher Performance to Quality Learning in Madrasah Aliyah (A Comparative Study between Madrasah Aliyah Model and Non-Model Madrasah Aliyah in West Java). Proceedings of the International Conference on Islamic Education (ICIE 2018), 261(Icie), 178-183. https://doi.org/10.2991/icie-18.2018.32. 